\title{
Chemical and petrographic fingerprinting of volcanic ashes as a tool to high-resolution stratigraphy of the upper Miocene Pisco Formation (Peru)
}

Giulia Bosio $_{a}$, Anna Gioncadab, Elisa Malinverno $a$, Claudio Di Celma, Igor Maria Villad-e, Giuseppe Cataldi $i_{b}$, Karen Gariboldib, Alberto Collaretaf, Mario Urbinag and Giovanni Bianuccib

(a) Dipartimento di Scienze dell'Ambiente e della Terra, Università di Milano-Bicocca, Milan, Italy g.bosio1@campus.unimib.it; elisa.malinverno@unimib.it

(b) Dipartimento di Scienze della Terra, Università di Pisa, via S. Maria 53, 56126 Pisa, Italy

anna.gioncada@unipi.it; peppe1984@hotmail.com; karen.gariboldi@for.unipi.it; giovanni.bianucci@unipi.it

(c) Scuola di Scienze e Tecnologie, Università di Camerino, Camerino, Italy

claudio.dicelma@unicam.it

(d) Institut für Geologie, Universität Bern, Bern, Switzerland igor.villa@geo.unibe.ch

(e) Centro Universitario Datazioni e Archeometria, Università di Milano-Bicocca, 20126 Milano, Italy

(f) Dottorato Regionale in Scienze della Terra Pegaso, Pisa, Italy alberto.collareta@for.unipi.it

(g) Departamento de Paleontología de Vertebrados, Museo de Historia Natural, Universidad Nacional Mayor de San Marcos, Lima, Peru

mariourbina01@hotmail.com

Corresponding author: Giulia Bosio g.bosio1@campus.unimib.it

\section{Abstract}

Tephra layers are a unique tool for stratigraphy. Their geologically instantaneous deposition together with their dispersion on wide areas make them a powerful instrument for dating and correlating simultaneous events at different localities. In this paper, we present and discuss the application of tephra fingerprinting in the upper Miocene portion of the Pisco Formation.

The Pisco Formation is an important marine vertebrate Fossil-Lagerstätte that crops out in the Ica Desert, on the Peruvian Coast. The paleontological relevance of this formation has entailed the necessity of reconstructing a chronostratigraphic framework, using ${ }^{40} \mathrm{Ar} /{ }^{39} \mathrm{Ar}$ dating and correlations on volcanic ashes. Tephra layers from the volcanic activity of the Peruvian Andes are very frequent in the Pisco Formation and many represent a primary air-fall deposition on the sea floor. Therefore, many samples from tephra layers within measured stratigraphic sections at different sites in the study area were fingerprinted with a combined approach, using petrographic and chemical analyses on phenocrysts and volcanic glasses, as well as glass shard morphology and granulometric analyses, performed on 53 selected samples, collected from different 
localities. Based on the results obtained, we correlate some tephra layers in localities at several km distance, where the correlation between the measured sections was previously only hypothetical. Major element chemistry of biotite proved a valuable tool to discriminate different tephra in the upper Miocene portion of the Pisco Formation, due to the presence of peraluminous as well as metaluminous compositions. This work shows that it is possible to apply tephra fingerprinting and tephrostratigraphy in a complex situation such as that represented by the Pisco Formation, where a high number of apparently similar volcanic ash layers were deposited in a shallow marine environment. The application of this correlation method allows us to increase the chronostratigraphic detail in the studied interval of the Pisco Formation, providing an accurate framework in which fossil marine vertebrates are stratigraphically located. The obtained high-resolution chronostratigraphy will greatly clarify the evolutionary history of Cetaceans.

\section{Highlights}

- Onshore forearc basins provide an archive of late Miocene Andean distal tephra

- Major element chemistry of glass and biotite allow fingerprinting tephra of Pisco Formation

- Biotite chemistry is a powerful tool for upper Miocene Peruvian tephra fingerprinting

- Tephra give a detailed chronostratigraphic framework for the Pisco marine vertebrate KonservatLagerstätte

\section{Keywords}

Tephrostratigraphy; Tephra fingerprinting; Fossil-Lagerstätte; Miocene; Pisco Formation; Central Andes

\section{Introduction}

Due to their regional dispersion, geologically instantaneous deposition, and the common presence of minerals suitable for radiometric age determination, the value of volcanic ashes as regional chronostratigraphic markers has long been recognized (Lowe et al., 2017).

Detailed chronostratigraphic reconstructions are particularly important for the sedimentary fill of the East Pisco Basin exposed on the southern Peruvian coast (Fig. 1A). The East Pisco Basin, indeed, hosts one of the most important world-class cetacean Fossil-Lagerstätten, with exceptionally well-preserved fossils of marine vertebrates (Bianucci et al., 2016a, 2016b). In particular, along the western side of the Ica River Valley, strata of the Mio-Pliocene Pisco Formation are characterized by fossil remains of cetaceans, both odontocetes and mysticetes, but also of pinnipeds, sea-birds, sea-turtles, crocodiles, sharks, and bony fish (Muizon, 1988; Bianucci et al., 2010, 2015, 2016c; Lambert et al., 2010, 2015, 2017a, 2017b; Parham and Pyenson, 2010; Esperante et al., 2015; Collareta et al., 2015; Gioncada et al., 2016; Stucchi et al., 2016; 
Marx et al., 2017). The correspondence between the stratigraphy and the vertebrate findings was a long-term neglected issue and each fossil-bearing locality was not correlated with the adjacent ones. In order to better understand qualitatively and quantitatively the evolution of its rich marine vertebrate fauna during a pivotal time frame for the evolutionary history of marine vertebrates, such as the late Miocene, the Pisco Formation needs the reconstruction of an accurate, high-resolution absolute and relative age framework. This age interval is characterized by a significant cetacean turnover outlined by the diversification of several lineages of crown neocetes as the delphinidians and the ziphiids among the odontocets, and the balaenopterids among the mysticetes (Fordyce and Muizon, 2001; Bianucci and Landini, 2017; Marx et al., 2015). Accurate dating of some taxa can also allow a better definition of several calibration points for molecular divergence estimated among crown neocetes (see,e.g. Lambert et al. 2017b).

The Pisco Formation is a diatomite-rich marine unit with numerous layers of volcanic ash representing primary air-fall events from the Peruvian Central Andes volcanoes and a very important tool to define its stratigraphic framework (Di Celma et al., 2017; Gariboldi et al., 2017). So far, their use has been limited to field correlations within a single locality and to obtain ${ }^{40} \mathrm{Ar} /{ }^{39} \mathrm{Ar}$ ages. With the aim of fully exploiting the potential of these volcanic ash layers for tephrostratigraphy, in this paper we fingerprint ash layers by a chemical and petrographic characterization and correlate them between different localities.

Fingerprinting of distal tephra is recognized as a useful method for stratigraphic reconstructions (D'Antonio et al., 2016) and is largely employed in the Quaternary (e.g. Zanchetta et al., 2011; D'Antonio et al., 2016) and to correlate the deposits of large eruptions of Central Andes (De Silva and Francis, 1989; Lebti et al., 2006; Breitkreutz et al., 2013).

In the Pisco Formation, however, the high number of ash layers interbedded within a monotonous diatomrich succession, the similarity of their geochemical features and components, and the possibility that sea currents affected both their grain size and composition during deposition, hamper the unequivocal identification of these ashes directly in the field. In this paper, we focus on some of the ash layers from the P2 depositional sequence, which is the youngest unconformity-bounded unit documented so far in the upper Miocene portion of the Pisco Formation (Di Celma et al., 2017) and the most studied one for its high paleontological content. We fingerprint tephra layers of the P2 sequence by using major element chemistry of biotite and glass combined with petrographic and granulometric features, with the aim to correlate stratigraphic sections in different localities and highlight the feasibility of an approach based on major element biotite chemistry. The same approach could be extended to other fossiliferous successions of the Pisco Basin relevant for the reconstruction of marine vertebrate evolution.

\section{Setting}

\subsection{Geological and volcanological setting}

The Peruvian margin is part of the long-lived convergent margin of South America and is interested by two extended structural ridges, the Outer Shelf High and the Upper Slope Ridge, dissecting the Peruvian coast 
into a series of Cenozoic forearc basins (Fig. 1A). The East Pisco Basin, the onshore part of one of these basins at $14^{\circ} 30^{\prime} \mathrm{S}$ of latitude, is confined by the igneous rocks of the Mesozoic Coastal Batholith to the east (Cobbing, 1999) and by Precambrian to Jurassic rocks of the Coastal Cordillera to the west (Romero et al., 2013). As described by previous authors (Dunbar et al., 1990; DeVries, 1998), this basin was interested by a discontinuous sediment deposition between the Eocene and the Pliocene. Starting from late Pliocene, the subduction of the aseismic Nazca Ridge beneath the South American plate has caused the uplift of the East Pisco Basin (Macharé \& Ortlieb 1992; Hampel et al. 2002), resulting in the onland exposure of its Eocene to Pliocene sedimentary fill.

The numerous volcanic ashes interbedded with the basin-filling sedimentary succession provide a snapshot of the long-lived activity of the Central Andes volcanoes, frequently punctuated by large explosive eruptions. The dispersion of Andean tephra, as demonstrated by historical examples (Adams et al., 2001) as well as by off-shore drilling programs logs (Hart and Miller, 2006), largely affected the margin with off-shore deposition of Plinian and of co-ignimbrite ashes. As reviewed by Mamani et al. (2010), the Central Andean margin has a very complex subduction-related history. The late Paleozoic to middle Cretaceous history was characterized by tectonic stretching, allowing the formation of a marine back-arc basin; a continuous relief, with a continental back-arc environment, formed in the time period from the late Cretaceous to the middle Oligocene, but the major crustal thickening typical of the Andean orogeny was developed only since the middle Oligocene (Mamani et al., 2010). These authors subdivide the continuous magmatic activity into four, partly overlapping, discrete phases: the Tacaza arc, from 30 to 24 Ma, the Huaylillas arc, between 24 and $10 \mathrm{Ma}$, the Lower Barroso arc, from 10 to $3 \mathrm{Ma}$ and the Upper Barroso arc, between 3 and 1 Ma. Voluminous Neogene and Quaternary ignimbrite deposits occur in southern Peru, testifying the main periods of intense and voluminous explosive activity of the arcs (Lebti et al., 2006; Thouret et al., 2007, 2016). According to the samples available to these authors, repeated pulses of ignimbrites occurred every 2-3.8 Ma between 24.5 and 9.0 Ma in the southern Peru and a quasi-continuous volcanism after $5 \mathrm{Ma}$ that produced four smaller ignimbrite sheets and pyroclastic density current deposits. The present-day active volcanic arc, or Western Cordillera, lies about $230 \mathrm{~km}$ east of the trench (Fig. 1B). In Southern Peru, the active volcanic arc ends at about $14^{\circ} \mathrm{S}$, in correspondence with the Nazca Ridge (Hampel, 2002) and with the change from "normal" to "flat" subduction.

\subsection{Stratigraphic and geochronological setting}

The lithostratigraphic units recognized by Dunbar et al. (1990) and DeVries (1998) are, from the oldest to the youngest, the Eocene Paracas Formation, the upper Eocene-lower Oligocene Otuma Formation, the upper Oligocene to lower Miocene Chilcatay Formation and the upper Miocene to Pliocene Pisco Formation. These formations are separated by regional unconformities marked by pebble- and boulder-grade conglomerates and represent long periods of subaerial exposure.

Muizon and Bellon (1980; 1986) and Dunbar et al. (1990) had already noticed the presence of "tuffaceous siltstones" in the Pisco Formation, but no one described the petrology and the chemistry of tephra layers. 
Some authors have provided ages of the Pisco Formation using $\mathrm{K} / \mathrm{Ar}$ and ${ }^{40} \mathrm{Ar} /{ }^{39} \mathrm{Ar}$ radiometric dating on these tephra beds (Muizon and Bellon 1980; 1986; Brand et al., 2011; Esperante et al., 2015), integrating the biostratigraphic framework obtained by diatoms, radiolarians and planktonic foraminifera (Macharè and Fourtanier 1987, Schrader and Ronning 1988, Tsuchi et al. 1988, Dunbar et al. 1990). These radiometric ages, however, are not placed in a stratigraphic context and, therefore, only provide age indications for individual localities without correlations among them.

Recently, the stratigraphy of the Pisco Formation has been re-examined in detail (Di Celma et al., 2016a, 2016b; 2017). In particular, in order to place its fossil vertebrates in a proper chronostratigraphic framework, new stratigraphically-constrained sediment samples for diatom biostratigraphy and ${ }^{40} \mathrm{Ar} /{ }^{39} \mathrm{Ar}$ isotope ages have been collected and analyzed (Gariboldi et al., 2017). The fossiliferous strata of the Pisco Formation exposed along the western side of the Ica River Valley have been divided into three fining-upward depositional sequences named, from the oldest to the youngest, P0, P1 and P2 and bounded by three regionally extensive erosional surfaces, PE0.0, PE0.1, and PE0.2 (Di Celma et al., 2017). Combined diatom biostratigraphy and tephrochronologic ${ }^{40} \mathrm{Ar} /{ }^{39} \mathrm{Ar}$ results demonstrate that in the study area the P1 sequence was deposited between 9.5 Ma and 8.9 Ma and the P2 sequence is younger than 8.5 Ma and older than 6.71 \pm 0.02 Ma (Di Celma et al., 2017; Gariboldi et al., 2017). With this approach, a detailed chronostratigraphic framework is being reconstructed, previous scattered radiometric data. The stratigraphic framework of the Pisco Formation has been much improved, and a nearly continuous record is now available. For this work, it is important to consider that sediments of the P2 sequence have been dated at the localities of Cerro los Quesos (14³0'59.0" S; 7542'59.1" W) and Cerro la Bruja (14³1'44.10" S; 7540'0.10" W), two fossiliferous areas located about $6 \mathrm{~km}$ apart (Fig. 1B), where most of the tephra layers studied in this paper were collected. From the oldest to the youngest, the ${ }^{40} \mathrm{Ar} /{ }^{39} \mathrm{Ar}$ ages obtained on biotite phenocrysts from samples collected at Cerro los Quesos are 7.55 $\pm 0.05 \mathrm{Ma}$ (CLQ-T49 at $128 \mathrm{~m}$ from the base of the measured section), $6.93 \pm 0.09 \mathrm{Ma}$ (CLQ-T1a at $238 \mathrm{~m}$ ) and an age older than $6.71 \pm 0.02 \mathrm{Ma}$ (CLQ-T9b at the very top of the measured section) (Gariboldi et al., 2017). In order to confirm the field-based correlation between the two stratigraphic sections measured at these localities, an additional ${ }^{40} \mathrm{Ar} /{ }^{39} \mathrm{Ar}$ age of $7.45 \pm 0.01$ Ma was obtained from biotite phenocrysts of the tephra layer LB-T11 in the Cerro la Bruja section (see the stratigraphic position in Fig. 9), mentioned as preliminary result in Di Celma et al. (2017).

\section{Methods}

An area of more than $240 \mathrm{~km}^{2}$ in the western side of the Ica River Valley was explored during several field campaigns between 2014 and 2016. In order to reconstruct the stratigraphy of this area, six stratigraphic sections, for a total of about 1200 meters of measured stratigraphy, were logged with a Jacob's Staff (Di Celma et al., 2016a, 2016b, 2017). In the course of measuring stratigraphic sections and prospecting the study area, more than 200 samples were collected from tephra layers; of these, 53 samples from layers interpreted as primary tephra were analyzed for mineral and glass chemistry for this work. The ash samples 
analyzed for tephrochronological and tephrostratigraphic purposes were collected in the localities of Cerro los Quesos, Cerro la Bruja, Cerro Colorado, Cerro Hueco la Zorra, Cerro Blanco, Cerro Toro Chico, Cerro Cadenas de los Zanjones and Cerro la Mama y la Hija (Fig. 2).

In the field, volcanic ash layers were described making observations on their lateral continuity, thickness, vertical grading, color, sedimentary structures and presence of phenocrysts. Samples were collected close to the base of the ash layer, avoiding the upper portion so as to exclude bioturbation, reworking, and mixing with non-volcanic sediments. In order to avoid the weathered particles, the superficial parts of the tephra layers were eliminated before sampling. Samples were examined under a stereomicroscope and prepared as smear slides for petrographic analysis and for a semi-quantitative component analysis, to check the presence of non-volcanic particles and evidence of alteration of volcanic components. Based on the results of this first screening, samples with more than $5 \%$ vol. of non-primary particles, which could not be interpreted as representative of the primary deposition on the sea surface of ashes of explosive eruptive events, were discarded (Tada et al., 2015; Griggs et al., 2014). Grain size analyses were performed with the Malvern Mastersizer 2000EтM Laser Granulometer at the University of Milano Bicocca. For each sample, three subsamples were made and each one of them was subject to three measurements. Grain size data were processed with the Grain Size Analysis Program GRADISTAT (Blott and Pye, 2001).

Samples were also wet sieved with meshes of 500, 250, 125 and $63 \mu \mathrm{m}$. Biotite and glass particles were randomly hand-picked under a stereomicroscope from the $250 \mu \mathrm{m}$ (for coarser ashes) and $125 \mu \mathrm{m}$ size fraction, mounted in resin, polished with silicon carbide and alumina and carbon-coated.

Glass shard morphology and mineral assemblages of the samples representing tephra of primary deposition of ashes were observed by optical microscopy on smear slides and analyzed by scanning electron microscopy (SEM) back-scattered imaging on the carbon-coated polished mounts, to fingerprint the petrographic and textural features of the juvenile volcanic components.

For glass and biotite chemistry, EPMA (Electron Probe Micro Analysis) and EDS (Energy-dispersive X-ray Spectroscopy) analyses were performed on at least 10-15 representative glass shards and 10 biotite phenocrysts (core and rim) per sample, in order to obtain a chemical fingerprinting of the tephra layers and an estimate of the weathering degree of biotite phenocrysts.

SEM-EDS analyses were carried out at the University of Pisa with a Philips ${ }^{\mathrm{TM}}$ XL30 scanning electron microscope with $20 \mathrm{kV}$ filament voltage, $5 \mathrm{nA}$ beam current and ZAF correction, in raster mode and 10x10 or 5x5 microns-size windows. EPMA analyses were performed with a JEOL JXA-8600 ${ }^{\mathrm{TM}}$ at Consiglio Nazionale delle Ricerche in Florence and with a JEOL 8200 Superprobe $^{\mathrm{TM}}$ at the University of Milan. Analytical conditions were $15 \mathrm{kV}$ accelerating voltage, 5nA beam current, $3 \mu \mathrm{m}$ beam focus for biotite and $10 \mu \mathrm{m}$ for glass shards.

\section{Results}

\subsection{Field data}


Along the measured stratigraphic sections, ash layers were more frequent in the P2 sequence than in the other sequences (about 20 tephra layers thicker than $2 \mathrm{~cm}$ every $100 \mathrm{~m}$ ) and particularly abundant in the diatomitic portion. The thickness, for the majority of the sampled tephra, ranges between 5 and $15 \mathrm{~cm}$. However, while their bases are commonly sharp and easy to recognize, their upper boundaries may be irregular or diffuse and not always clearly detectable, particularly in diatomite-rich sediments (Fig. 3A, B). Some thicker tephra (up to $50 \mathrm{~cm}$ ), organized in different sublayers, have been found. Except for very finegrained and crystal-free ashes, the ash beds show an evident normal grading and the base is typically characterized by a concentration of coarser particles and crystals (Fig. 3). Although in most cases they are unconsolidated, in some cases the volcanic ash layers are cemented by secondary minerals such as gypsum and jarosite. At the base, a hard gypsum/anhydrite crust of a few mm thickness is commonly found. The color in the field is usually grey to light grey, with transparent glass and a "pepper and salt" appearance due to biotite (Fig. 3B, C). Thin (2-3 cm) dark grey tephra were found, although less frequently. Internally, a variety of soft-sediment deformation structures, including load casts, small-scale folding, convolutions, and dish and pillars structures, have been observed in some of the thicker layers (CLQ-T1 and CLQT-12). These deformation structures may have developed by rapid deposition of the thick ash layers on waterlogged diatom ooze, which may have started consolidation in the immediately underlying sediments (Pedersen and Surlyk, 1977). Waters escaping from such layers may liquefy or fluidize the lower portion of the ash, resulting in sinking of overlying denser portion into the liquidized lower portion (load casts) and compensatory upward intrusion (diapirs and flames) of the latter into the overlying sediment (Owen, 2003). In one case, this deformation structures are recognizable in the same tephra at $6 \mathrm{~km}$ of distance, i.e. CLQT12 and LB-T7 ash layers (see Fig. 3).

\subsection{Petrographic fingerprinting of tephra}

\subsubsection{Grain size distribution and components of volcanic ash}

246 The grain sizes of the sampled tephra layers fall in the range of fine-grained sand to silt. Inspections under 247 SEM of bulk samples of some particularly coarse tephra and of the coarser fractions of wet sieved samples 248 indicate that, in some cases, a minor fraction of coarser sand is made of strongly agglomerated particles, 249 cemented by supergene secondary minerals. However, most of the samples consist of loose ash, nearly unaffected by secondary cements. As shown in Fig. 4, the grain-size distribution is unimodal or bimodal and the classification is dominated by fine-grained ashes, very fine-grained ashes or extremely fine-grained ashes (Table S1), mainly moderately to well sorted (White and Houghton, 2006). In case of field evidence of sublayers (e.g. CLQ-T1, CC-T1), each sublayer was sampled, and the lower sublayer is usually coarser than the upper one; only in one case (CLQ-T9), a normally graded coarser layer directly overlies a well sorted fine-grained ash layer, indicating deposition of ashes of two distinct, but relatively close, eruptive events. In several cases, the grain-size distribution is bimodal: rather than fine-grained ash aggregation, we suggest to interpret the coarse-grained and the fine-grained modes as, respectively, the Plinian ash and the coignimbrite ash, following observations of Engwell et al. (2014). 
The component particles are dominated by glass shards (> 85-95\% in volume), without visible evidence of alteration, and variable amounts of juvenile phenocrysts (biotite, sanidine and plagioclase, in some cases amphibole, in one case muscovite) and traces of terrigenous and biogenic materials (Table S1). The ash layers containing more than $10 \%$ of eompenent particles extraneous to the primary volcanic material, such as diatom frustules, rock fragments, heterogeneous crystal assemblages with olivine, pyroxene, quartz and reddish aggregates probably consisting of Fe-hydroxides and clays, were interpreted as tephra modified by reworking and the samples were not further processed. The 53 ash layers interpreted as primary tephra were studied for textural and chemical characteristics.

\subsubsection{Texture of ash particles}

Glass shard morphology is a promising tool for distinguishing and correlating tephra layers (Lowe, 2011). Optical and scanning electron microscopy allowed the study of the glass morphologies and characteristics. Five main groups of glass shards were identified (Fig. 5): bubble-wall shards, with round and concave sides; vesiculated shards, with variable vesicularity; stretched, vesiculated shards with strongly elongate vesicles due to stretching; platy shards, without any vesicles and not stretched; shards with microlites, mainly plagioclase. Tephra were fingerprinted based on the prevalent shard features in the 125-250-micron size fraction. Samples from tephra layers supposed to be the same level from different localities show similar glass shard morphologies and characteristics (Table S1).

BSE imaging of glass shards did not reveal, except in some cases, the formation of hydration cracks or of secondary minerals at the expense of the glass (Fig. 5). Most biotite phenocrysts, inspected by means of BSE imaging, did not show obvious secondary alteration minerals along cleavages. They frequently show accessory minerals apatite and zircon as inclusions, as well as glass inclusions.

\subsubsection{Volcanic glass chemistry}

The chemical composition of volcanic glass was analyzed avoiding the regions very close to vesicles and cracks, which could be more deeply affected by alteration, and microlites. As regards microlites, these are absent in most samples but are common in a few tephra having dark grey color and an andesitic composition. For each tephra, glass shards were analyzed and the mean and standard deviation recalculated to check for homogeneity. Samples with high standard deviation in glass analysis were discarded, except for a few cases with two distinct homogeneous populations, which could be interpreted as two eruptive events close in time or as the result of magma mixing/mingling processes. Since some hydration affected at variable degree all the analyzed ashes, resulting in microprobe totals of 89 to 95\% (Table 1), the analyses were recalculated to 100 to allow comparing tephra with different degrees of hydration in the same diagrams.

The results are shown in a $\mathrm{K}_{2} \mathrm{O}$ vs. $\mathrm{SiO}_{2}$ diagram in Fig. 6, with fields for arc-related volcanic rocks following Peccerillo and Taylor (1987). The silica content ranges from 57 to 78 wt\%. As regards the lowsilica glass compositions, these belong to the few dark gray tephra with microlitic shards. Glass chemistry indicates for these ashes an andesitic to dacitic composition when the major elements are recalculated to 100, 
but the silica content of residual glass can be higher than the magma composition due to the effect of microlite crystallization and to secondary hydration. As regards the silicic tephra samples, the recalculation to 100 and the alkali loss revealed by the negative trends in some samples (see in Fig. 6) results in a higher silica content compared to the original erupted magma. However, considering that the samples suspected of large hydration and/or alkali loss were discarded and that the samples in the diagram have a similar hydration degree, we conclude that the Pisco Formation tephra have a large chemical variation, from andesite to rhyolite. Moreover, for the purpose of fingerprinting, it is worth noting that, even if the composition of glass of most tephra plots in the rhyolite field, it is possible to distinguish different, non-overlapping groups of tephra.

\subsubsection{Biotite chemistry}

Biotite phenocrysts are homogeneous or slightly zoned for what concerns the core-to-rim major elements compositional range (Table 2). The intra-sample compositional variability is moderate in most cases (Fig. 7A), and a few samples present some outliers (biotite phenocrysts with very different composition, which can be interpreted as xenocrysts entrained within the ash layer or xenocrysts in the erupted magma). A few samples show bimodal (e.g. CLQ-T9b) or very heterogeneous biotite chemistry (e.g. LB-T2). In terms of mica classification (Rieder et al., 1998), the analyses plot in the biotite field, with a trend to the siderophyllite end-member (Fig. 7B).

Interestingly, the significant differences in the major element compositions of biotite, especially the $\mathrm{Mg} / \mathrm{Fe}$ ratio, expressed as $\mathrm{Mg}_{\mathrm{V}}=\mathrm{Mg} /(\mathrm{Mg}+$ Fetot $+\mathrm{Mn})$, cannot be ascribed entirely to alteration (see Table 2). Alteration of biotite by weathering may result in Fe oxidation, loss of Mg resulting in low $\mathrm{Mg}_{\mathrm{v}}$, loss of interlayer K, while $\mathrm{Al}$ and $\mathrm{Ti}$ are retained (Gilkes and Suddhiprakarn, 1979), but these chemical transformations correspond to physical and mineralogical features which do not apply to these samples (Fig. 5). The large chemical variations in major elements ( $\left.\mathrm{Mg}_{\mathrm{v}}\right)$, as well as in minor elements as $\mathrm{Ti}, \mathrm{Al}, \mathrm{Ba}$ and $\mathrm{Mn}$, can be ascribed to the physico-chemical features of the magma from which biotite crystallized and, therefore, can be used for discriminating biotite from different eruptions. Accordingly, a rough correlation exists between biotite $\mathrm{Mg}_{\mathrm{v}}$ and the magmatic differentiation degree indicated by the glass composition (Fig..., Table...).

In some cases, two biotite populations with different composition have been observed within the same tephra, e.g. samples LB-T19 and CLQ-T23 (Fig. 7A). This feature, which is not correlated to alteration evidence (such as low totals, low K), could be interpreted as coeval eruption of two different volcanoes, two events close in time by the same volcano, or eruption of a mingled magma (Lebti et al., 2006; Shane et al., 2008), and is, thus, an additional characteristic useful for the unequivocal identification of tephra.

The strong variation in Al content of biotite accompanied by similarly silicic glasses indicates remarkable differences in magma chemistry of the silicic magmas. In fact, when the chemical composition of biotite is plotted in the ternary discrimination diagram of Abdel-Rahman (1993), as shown in Fig. 7C, two main groups are evident: the calcalkaline orogenic one and the one. The identification of peraluminous tephra, as 
the pair CLQ-T23 and LB-T19 and the sample MH-T4, by means of biotite is very relevant for correlation. The major element composition of mica grains is more robust than that of glass due to its reactivity to alteration. The removal of mobile cations results in an apparent increase of immobile elements (Al, Ti), simulating peraluminous compositions.

Another biotite cluster with a peculiar composition, the pair CLQ-T13b and LB-T10, is shown in Fig. 7C. It is easily recognizable and very different from all other mica samples, and therefore quite useful for tephra fingerprinting.

\section{Discussion}

\subsection{Applying tephra fingerprinting for high-resolution correlation in the Pisco Formation}

The mineral chemistry data presented in Gariboldi et al. (2017) indicate that compositionally different sanidine-plagioclase pairs of clusters may be recognized in different rhyolitic samples, suggesting that in the Pisco Formation mineral chemistry could be used to fingerprint ash layers for long-distances correlation purposes. In this work, 53 samples of P2 volcanic ash layers consisting of over 95\% volcanic glass and minor amounts of juvenile phenocrysts, considered representing primary air-fall events from the Peruvian Central Andes volcanoes, have been studied for fingerprinting.

Data used for fingerprinting the P2 tephra layers include petrographic description of glass and phenocrysts (modal analysis on smear slides, glass shard morphology by Scanning Electron Microscopy), grain size analysis by Laser Granulometry, major element chemistry of biotite and glass by Electron Probe Microanalysis. Using these methods, we were able to establish some correlations between stratigraphic sections. Chemical analyses on biotite phenocrysts show that major ( $\mathrm{Mg}, \mathrm{Fe}$ ) and minor ( $\mathrm{Ti}, \mathrm{Al}, \mathrm{Ba}, \mathrm{Mn}$ ) elements can highlight strong differences in the composition, not due to alteration. In general, different samples or group of samples plot in well-defined and non-overlapping clusters, which can be identified in one or more suitable bivariate diagrams. In particular, for the localities of Cerro los Quesos and Cerro la Bruja, we can see that there are some perfectly overlapping tephra pairs (Fig. 8), and different from all others: CLQ-T23 / LB-T19 (the tephra pair containing each two distinct mica populations), CLQ-T21 / LBT17, CLQ-T16 / LB-T8, CLQ-T15 / LB-T11, CLQ-T13b / LB-T10. The overlapping composition can also be observed in the tephra pair CLQ-T17 / LB-T15, which shows a very dispersed mica composition unrelated to that of glass (Fig. 6), possibly due to (primary or secondary) mixing of ashes from different eruptions. Figure 8 also demonstrates the chemical identity of samples BL-T1 and LZ-T1 from Cerro Blanco and Cerro Hueco la Zorra respectively, two localities at $6 \mathrm{~km}$ distance from each other.

In Figure 9, we can observe five of the correlated tephra along 60 meters of the measured sections at Cerro los Quesos (between 155 and $220 \mathrm{~m}$ ) and Cerro la Bruja (between 160 and $220 \mathrm{~m}$ ). The $\mathrm{Ti}$ and $\mathrm{Al}$ concentrations and the $\mathrm{Mg} / \mathrm{Fe}$ ratio ( $\mathrm{Mg}_{\mathrm{v}}$ ) of biotite phenocrysts is typical of each layer and can identify pairs of the same tephra layer in the two stratigraphic sections,. In several cases, grain size validates the correlation, showing a correspondence of the frequency distribution curves; however, the effect of marine currents in redistributing the component particles during the deposition could play a second-order role. 
Chemistry and morphology of volcanic shards give a further characterization useful to fingerprint tephra. Correlated tephra layers based on biotite chemistry also show an overlap of the glass compositions of the following pairs at Cerro los Quesos and Cerro la Bruja: CLQ-T23 / LB-T19, CLQ-T17 /LB-T15, CLQ-T16 /LB-T8, CLQ-T15 /LB-T11, CLQ-T13b /LB-T10. The tephra pair BL-T1 /LZ-T1 (Cerro Blanco and Cerro Hueco la Zorra, respectively) also overlap (Fig. 6). The compositional correlation is also supported by the glass morphology and characteristics: pairs of correlated tephra show similarities in the vesicularity, stretching, presence of microlites and glass shape.

Tephra fingerprinting and correlation provides a well defined and detailed chronostratigraphy of the P2 sequence at the two localities of Cerro los Quesos and Cerro la Bruja. At these two localities, the measured stratigraphic sections were previously correlated on stratigraphic and chronostratigraphic basis (Di Celma et al., 2017). ${ }^{40} \mathrm{Ar} /{ }^{39} \mathrm{Ar}$ ages at Cerro los Quesos, from the oldest to the youngest $7.55 \pm 0.05 \mathrm{Ma}, 6.93 \pm 0.09$ Ma and an age older than $6.71 \pm 0.02 \mathrm{Ma}$, fit with the ${ }^{40} \mathrm{Ar} /{ }^{39} \mathrm{Ar}$ age obtained from an ash layer at Cerro la Bruja, i.e. $7.45 \pm 0.01 \mathrm{Ma}$, confirming the tephra correlations based on fingerprinting. The improved chronostratigraphy benefits the paleontological reconstruction of the P2 sequence. We also observe that there are many tephra that do not occur in both localities. The reason is probably due to disturbances in the depositional environment, such as marine currents and the shallow water context, which cause a laterally discontinuous sediment deposition.

Even in such a complex sedimentary environment, we demonstrate that a petrographic and chemical fingerprinting can be used successfully. The identification of several ash layers with a peculiar biotite chemical composition (e.g. MH-T4, CC-T22 in Table S1), which were recognized in other localities of the Ica Desert thanks by biotite fingerprinting, is an encouraging validation of our approach. Biotite has been already used for Andean tephrostratigraphy, as well as amphibole (De Silva et al. 1989, Lebti et al. 2006). Biotite is really frequent as a phenocryst in Andean explosive eruptions and it can be found enriched in their distal deposits (e.g. Rose and Chesner, 1987), due to the fact that it is transported highly better than other phenocrysts (feldspars, amphibole). The relative ease with which non-stoichiometric mica compositions reveal alteration means that unaltered mica can be confidently recognized as juvenile in primary ash layers. The composition of feldspars can be used as an additional discriminant, if no biotite phenocrysts are found, as shown by Gariboldi et al. (2017) in some P2 tephra.

\subsection{Implications}

The present results clearly show that biotite chemistry is a particularly powerful tool for characterizing tephra. The precise reconstruction of the stratigraphic framework at some fossiliferous localities, such as Cerro los Quesos and Cerro la Bruja, allowed us to reconstruct with great bio- and chrono-stratigraphic detail the fossil record in the continuous P2 sequence between about 8.5 and 6.7 Ma, a very important time interval in the evolutionary history of different groups of marine vertebrates such as cetaceans and pinnipeds. 


\section{Conclusion}

The regional dispersion and the geologically instantaneous deposition of tephra layers are a great advantage for tephrostratigraphy and tephrochronology. A chemical and petrographic fingerprinting of the ashes enables a bed-by-bed correlation even over relatively long distances. When supplemented by absolute age dating of suitable samples, the reconstruction of an integrated chronostratigraphic framework becomes possible.

More than 200 tephra samples were collected in the Ica Desert of Peru, along measured stratigraphic sections in different localities. In this work, which is focused on the youngest depositional sequence of the Pisco Formation, P2, we selected 53 ash layers to show how tephra can be used to correlate different localities.

The difficulties found in the Pisco Formation in using tephra as a correlation tool reside in the broadly similar glass or mineral chemistry, the local weathering, the disturbance in deposition due to marine currents and changes in depositional environments among different localities. Despite these issues, the petro-chemical diversity of the volcanic ashes deriving from the Andean volcanoes is high. This encourages using the major element composition of glass and biotite to fingerprint and correlate stratigraphic sections in different localities. The chemical correspondence of the obtained data allowed us to verify stratigraphic correlations that were hypothesized in the field and to trace tephra layers across distant outcrop localities, such as from Cerro los Quesos to Cerro la Bruja. In particular, volcanic biotite chemistry, showing marked variations in $\mathrm{Al}$, Ti, Mn, Mgv, proved to be a powerful tool for tephra fingerprinting in the Pisco Formation, besides being the main mineral useful for absolute dating.

Tephra correlation based on the context of radiometric ages with petrographic and chemical fingerprinting is a promising tool to correlate distant stratigraphic sections and to increase the chronostratigraphic resolution, in the complex sedimentation environment of the Pisco Formation. Extending integrated tephra fingerprinting to proximal fallout deposits near their eruptive sources may improve the volcanological information on Peruvian Andes during the Miocene,

\section{Acknowledgments}

This study was supported by grants from the Italian Ministero dell'Istruzione dell’Università e della Ricerca (PRIN Project 2012YJSBMK) and by a National Geographic Society Committee for Research Exploration grant (9410-13) to G. Bianucci. The authors thanks Nicoletta Fusi for the granulometric analyses and Andrea Risplendente for the help with the microprobe analyses.

\section{References}

Abdel-Rahman A.M. (1994). Nature of biotites from alkaline, calc-alkaline, and peraluminous magmas. Journal of Petrology, 35: 525-541. 
Adams, N. K., de Silva, S. L., Self, S., Salas, G., Schubring, S., Permenter, J. L., \& Arbesman, K. (2001). The physical volcanology of the 1600 eruption of Huaynaputina, southern Peru. Bulletin of Volcanology, 62(8), 493-518.

Bianucci G. \& Landini W (2007). Fossil history. In: Miller D.L. (Ed). Reproductive biology and phylogeny of Cetacea: whales dolphins and porpoises. Enfield (New Hampshire): Science Publishers, 35-93.

Bianucci G., Lambert O. \& Post K. (2010) - High concentration of long-snouted beaked whales (genus Messapicetus) from the Miocene of Peru. Palaeontology, 53: 1077-1098.

Bianucci G., Di Celma C., Collareta A., Landini W., Post K., Tinelli C., de Muizon C., Bosio G., Gariboldi K., Gioncada A., Malinverno E., Cantalamessa G., Altamirano-Sierra A., Salas-Gismondi R., Urbina M. \& Lambert O. (2016a). Fossil marine vertebrates of Cerro Los Quesos: Distribution of cetaceans, seals, crocodiles, seabirds, sharks, and bony fish in a late Miocene locality of the Pisco Basin, Peru. Journal of Maps, 12: 1037-1046.

Bianucci, G., Di Celma, C., Landini, W., Post, K., Tinelli, C., de Muizon, C., Gariboldi, K., Malinverno, E., Cantalamessa, G., Gioncada, A., Collareta, A., Salas-Gismondi, R., Varas, R., Stucchi, M., Urbina, M. \& Lambert, O. (2016b). Distribution of fossil marine vertebrates in Cerro Colorado, the type locality of the giant raptorial sperm whale Livyatan melvillei (Miocene, Pisco Formation, Peru). Journal of Maps, 12, 543557.

Bianucci G., Di Celma C., Urbina M. \& Lambert, O. (2016c). New beaked whales from the late Miocene of Peru and evidence for convergent evolution in stem and crown Ziphiidae (Cetacea, Odontoceti). PeerJ, 4:e2479. DOI10.7717/peerj.2479

Blott S.J. \& Pye K. (2001). Gradistat: a grain size distribution and statistics package for the analysis of unconsolidated sediments. Earth Surface Processes and Landforms, 26: 1237-1248.

Brand L.R., Urbina M., Chadwick A., DeVries T.J. \& Esperante R. (2011). A high resolution stratigraphic framework for the remarkable fossil cetacean assemblage of the Miocene/Pliocene Pisco Formation, Peru. Journal South American Earth Sciences, 31: 414-425.

Cioni, R., D'Oriano, C., \& Bertagnini, A. (2008). Fingerprinting ash deposits of small scale eruptions by their physical and textural features. Journal of Volcanology and Geothermal Research, 177(1), 277-287.

Cobbing E.J. (1999). The Coastal Batholith and other aspects of Andean magmatism in Peru. In: Castro, A., Fernandez, C. \& Vigneresse, J. L. (Eds). Understanding Granites. Integrating New and Classical Techniques. Geological Society, London, Special Publications, 168: 111-122.

Collareta A., Landini W., Chacaltana C., Valdivia W., Altamirano-Sierra A., Urbina M. \& Bianucci G. (2017). A well preserved skeleton of the fossil shark Cosmopolitodus hastalis from the late Miocene of Peru, featuring fish remains as fossilized stomach contents. Rivista Italiana di Paleontologia e Stratigrafia, 123: $11-22$. 
D'Antonio, M., Mariconte, R., Arienzo, I., Mazzeo, F. C., Carandente, A., Perugini, D., ... \& Civetta, L. (2016). Combined Sr-Nd isotopic and geochemical fingerprinting as a tool for identifying tephra layers: Application to deep-sea cores from Eastern Mediterranean Sea. Chemical Geology, 443, 121-136.

De Silva, S. L., \& Francis, P. W. (1989). Correlation of large ignimbrites-two case studies from the Central Andes of Northern Chile. Journal of Volcanology and Geothermal Research, 37(2), 133-149.

Di Celma C., Malinverno E., Cantalamessa G., Gioncada A., Bosio G., Villa I.M., Gariboldi K., Rustichelli A., Pierantoni P.P., Landini W., Tinelli C., Collareta A. \& Bianucci G. (2016a) - Stratigraphic framework of the late Miocene Pisco Formation at Cerro Los Quesos (Ica Desert, Peru). Journal of Maps, 12: 1020-1028.

Di Celma C., Malinverno E., Gariboldi K., Gioncada A., Rustichelli A., Pierantoni P.P., Landini W., Bosio G., Tinelli C. \& Bianucci G. (2016b) - Stratigraphic framework of the late Miocene to Pliocene Pisco Formation at Cerro Colorado (Ica Desert, Peru). Journal of Maps, 12: 515-557.

Di Celma C., Malinverno E., Bosio G., Collareta A., Gariboldi K., Gioncada A., Molli G., Basso D., VarasMalca R., Pierantoni P.P., Villa I.M., Lambert O., Landini W., Sarti G., Cantalamessa G., Urbina M., Bianucci G. (2017). Sequence stratigraphy and palaeontology of the upper Miocene Pisco Formation along the western side of the lower Ica valley (Ica desert, Peru). Rivista Italiana di Paleontologia e Stratigrafia, 123, 255-274.

Dunbar R.B., Marty R.C. \& Baker P.A. (1990). Cenozoic marine sedimentation in the Sechura and Pisco basins, Peru. Palaeogeography, Palaeoclimatology, Palaeoecology, 77: 235-261.

Engwell S.L., Sparks R.S.J. \& Carey S. (2014). Physical characteristics of tephra layers in the deep sea realm: the Campanian Ignimbrite eruption. In: Austin, W. E. N., Abbott, P. M., Davies, S. M., Pearce, N. J. G. \& Wastegard, S. (Eds). Marine Tephrochronology. Geological Society, London, Special Publications, 398: 47-64.

Esperante R., Brand L.R., Chadwick A.V. \& Poma O. (2015). Taphonomy and paleoenvironmental conditions of deposition of fossil whales in the diatomaceous sediments of the Miocene/Pliocene Pisco Formation, southern Peru - a new fossil-lagerstätte. Palaeogeography, Palaeoclimatology, Palaeoecology, 417: 337-370.

Fordyce R.E. \& Muizon C. de (2001). Evolutionary history of cetaceans: a review. In: Mazin J.-M. \& de Buffrénil V. (Eds). Secondary adaptation of tetrapods to life in water. München: Verlag Dr. Friedrich Pfeil, 169-233.

Gariboldi, K. (2016). A note on diatom stratigraphic markers in upper Miocene sediments of the Pisco Formation, Peru, and description of Delphineis urbinai sp. nov. Diatom Research, 31(3): 285-301.

Gariboldi K., Bosio G., Malinverno E., Gioncada A., Di Celma C., Villa I.M., Urbina M. \& Bianucci G. (2017). Biostratigraphy, geochronology and sedimentation rates of the upper Miocene Pisco Formation at 
two important marine vertebrate fossil-bearing sites of southern Peru. Newsletter on Stratigraphy, 50/4: 417444.

Gioncada, A., Collareta, A., Gariboldi, K., Lambert, O., Di Celma, C., Bonaccorsi, E., ... \& Bianucci, G. (2016). Inside baleen: Exceptional microstructure preservation in a late Miocene whale skeleton from Peru. Geology, 44(10), 839-842.

Griggs, A. J., Davies, S. M., Abbott, P. M., Rasmussen, T. L., \& Palmer, A. P. (2014). Optimising the use of marine tephrochronology in the North Atlantic: a detailed investigation of the Faroe Marine Ash Zones II, III and IV. Quaternary Science Reviews, 106, 122-139.

Hampel A. (2002). The migration history of the Nazca Ridge along the Peruvian active margin: a reevaluation. Earth and Planetary Science Letters, 203: 665-679.

Hart D. \& Miller D.J. (2006). Analysis and correlation of volcanic ash in marine sediments from the Peru margin, Ocean Drilling Program Leg 201: explosive volcanic cycles of the north-central Andes. In Jørgensen, B.B., D’Hondt, S.L., and Miller, D.J. (Eds.), Proc. ODP, Sci. Results, 201, 1-43.

Lambert O., Bianucci G., Post K., Muizon C. de, Salas-Gismondi R., Urbina M. \& Reumer J. (2010). The giant bite of a new raptorial sperm whale from the Miocene epoch of Peru. Nature, 466: 105-108.

Lambert O., Collareta A., Landini W., Post K., Ramassamy B., Di Celma C., Urbina M. \& Bianucci G. (2015) - No deep diving: evidence of predation on epipelagic fish for a stem beaked whale from the late Miocene of Peru. Proc. Royal Soc. London Part B: Biol. Sci., 282: article no. 20151530.

Lambert O., Bianucci G. \& Muizon C. de. (2017a). Macroraptorial sperm whales (Cetacea, Odontoceti, Physeteroidea) from the Miocene of Peru. Zool. J. Linn. Soc., 179: 404-474.

Lambert O., Bianucci G., Urbina M. \& Geisler J.H. (2017b). A new inioid (Cetacea, Odontoceti, Delphinidae) from the Miocene of Peru and the origin of modern dolphin and porpoise families. Zool. J. Linn. Soc. 179(4): 919-946.

Lebti P.P., Thouret J.C., Worner G. \& Fornari M. (2006). Neogene and Quaternary ignimbrites in the area of Arequipa, Southern Peru: Stratigraphical and petrological correlations. Journal of Volcanology and Geothermal Research, 154: 251-275.

Lowe D.J. (2011). Tephrochronology and its application: A review. Quaternary Geochronology 6: 107-153. Lowe D. J., Pearce N. J., Jorgensen M. A., Kuehn S. C., Tryon C. A. \& Hayward C. L. (2017). Correlating tephras and cryptotephras using glass compositional analyses and numerical and statistical methods: Review and evaluation. Quaternary Science Reviews, 175, 1-44.

Macharé, J., Fourtanier, E. (1987). Datations des formations tertiaires du bassin de Pisco (Pérou) à partir d'associations de diatomées. Comptes rendus de l’Académie des sciences. Série 2, Mécanique, Physique, Chimie, Sciences de l'univers, Sciences de la Terre, 305(5): 407-412. 
Macharé J. \& Ortlieb L. (1992). Plio-Quaternary vertical motions and the subduction of the Nazca Ridge, central coast of Peru. Tectonophysic, 205: 97-108.

545 Mamani M., Worner G. \& Sempere T. (2010). Geochemical variations in igneous rocks of the Central 546 Andean orocline $\left(13^{\circ} \mathrm{S}\right.$ to $\left.18^{\circ} \mathrm{S}\right)$ : Tracing crustal thickening and magma generation through time and space. 547 Geological Society of America Bulletin, 122: 162-182.

548 Marx, F. G., Collareta, A., Gioncada, A., Post, K., Lambert, O., Bonaccorsi, E., ... \& Bianucci, G. (2017). 549 How whales used to filter: exceptionally preserved baleen in a Miocene cetotheriid. Journal of Anatomy. 550 Marx F.G., Lambert O. \& Uhen M.D. (2016). Cetacean paleobiology; In: M. Benton (Ed.). Topics in 551 Paleobiology. Chichester, UK: John Wiley \& Sons, Ltd, 319.

552 Muizon C. de \& Bellon H. (1980). L’âge mio-pliocène de la formation Pisco, Pérou. Comptes Rendus de 553 l’Académie des Sciences de Paris, 290, D: 1063-1066.

554 Muizon, C. de, Bellon, H., 1986. Nouvelles donn ees sur l'âge de la Formation Pisco (Pérou). Comptes 555 Rendus de l’Académie des Sciences de Paris, 303, II (15): 1401-1404.

556 Pedersen G.K. \& Surlyk F. (1977). Dish structures in Eocene volcanic ash layers, Denmark. Sedimentology, 557 24: 581-590. doi:10.1111/j.1365-3091.1977.tb00140.x

558 Perkins M.E., Brown F.H., Nash W.P., McIntosh W. \& Williams S.K. (1998). Sequence, age, and source of 559 silicic fallout tuffs in middle to late Miocene basins of the northern Basin and Range province. Geological 560 Society of America Bulletin, 110, 3: 344-360.

561 Romero D., Valencia K., Alarcon P., Pena D. \& Ramos V.A. (2013). The offshore basement of Perú: 562 Evidence for different igneous and metamorphic domains in the forearc. Journal of South American Earth 563 Sciences, 42: 47-60.

564 Schrader H. \& Ronning P. (1988). Diatom biostratigraphy and coastal upwelling interpretation. In: Dunbar, 565 R. B., Baker, P. A. (Eds.), Cenozoic Geology of the Pisco Basin, IGCP no. 156 Guidebook to Field 566 Workshop, May 1988, Lima, 135-140.

567 Shane P., Smith V. \& Nairn I. (2003). Biotite composition as a tool for the identification of Quaternary 568 tephra beds. Quaternary Research, 59: 262-270.

569 Shane, P., Nairn, I. A., Martin, S. B., \& Smith, V. C. (2008). Compositional heterogeneity in tephra deposits 570 resulting from the eruption of multiple magma bodies: implications for tephrochronology. Quaternary 571 International, 178(1), 44-53.

572 Smith V.C., Pearce N.J.C., Matthews N.E., Westgate J.A., Petraglia M.D., Haslam M., Lane C.S., Korisettar 573 R., Pal J.N. (2011). Geochemical fingerprinting of the widespread Toba tephra using biotite compositions. 574 Quaternary International, 246: 97-104. 
Stucchi M., Varas-Malca R.M. \& Urbina-Schmitt M. (2016). New Miocene sulid birds from Peru and considerations on their Neogene fossil record in the Eastern Pacific Ocean. Acta Palaeontol. Pol., 61: 417427.

Tada R., Murray R.W., Alvarez Zarikian C.A., Anderson Jr. W.T., Bassetti M.-A., Brace B.J., Clemens S.C., da Costa Gurgel M.H., Dickens G.R., Dunlea A.G., Gallagher S.J., Giosan L., Henderson A.C.G., Holbourn A.E., Ikehara K., Irino T., Itaki T., Karasuda A., Kinsley C.W., Kubota Y., Lee G.S., Lee K.E., Lofi J., Lopes C.I.C.D., Peterson L.C., Saavedra-Pellitero M., Sagawa T., Singh R.K., Sugisaki S., Toucanne S., Wan S., Xuan C., Zheng H., Ziegler M. (2015). Methods. The Expedition 346 Scientists Proceedings of the Integrated Ocean Drilling Program, Volume 346.

Thornburg T.M. \& Kulm L.D. (1981) - Sedimentary basins of the Peru continental margin: Structure, stratigraphy, and Cenozoic tectonics from $6^{\circ} \mathrm{S}$ to $16^{\circ} \mathrm{S}$ latitude. In: Kulm L.D., Dymond J., Dasch E.J. \& Hussong D.M. (Eds) - Nazca plate: Crustal formation and Andean convergence. Geological Society of America, Mem., 154: 393-422.

Thouret J.C., Worner G., Gunnel Y., Singer B., Zhang X. \& Souriot T. (2007). Geochronologic and stratigraphic constraints on canyon incision and Miocene uplift of the Central Andes in Peru. Earth and Planetary Science Letters, 263: 151-166.

Thouret J.C., Jicha B.R., Paquette J.L. \& Cubukcu E.H. (2016). A 25 myr chronostratigraphy of ignimbrites in south Peru: implications for the volcanic history of the Central Andes. Journal of the Geological Society, doi:10.1144/jgs2015-162

Tsuchi R., Shuto T., Takayama T., Fujiyoshi A., Koizumi I., Ibaraki M., Rangel Z. C., Aldana A. M. (1988). Fundamental Data on Cenozoic Biostratigraphy of the Pacific Coast of Peru. In: Tsuchi R. (Ed.), Report of Andean studies, Shizuoka University, 3: 45-70.

White J. D. L. \& Houghton B. F. (2006). Primary volcaniclastic rocks. Geology, 34(8): 677-680.

Zanchetta, G., Sulpizio, R., Roberts, N., Cioni, R., Eastwood, W. J., Siani, G., ... \& Santacroce, R. (2011). Tephrostratigraphy, chronology and climatic events of the Mediterranean basin during the Holocene: an overview. The Holocene, 21(1), 33-52.

\section{Captions}

Fig. 1 - Map of the major sedimentary basins and volcanism in the Peruvian coast. A. Sedimentary basins are indicated with names in blue. Major structural high as the Coastal Batholith, Outer Shelf High and Upper Slope Ridge are represented in red-yellow shades. The green square highlighting the East Pisco Basin indicates the study area. B. Volcanism and magmatic arcs during the Cenozoic. From Mamani 
Fig. 2 - Ica Desert localities. Main localities in the Ica Desert, where the studies of this paper are focused.

Fig. 3 - Tuff layer interbedded in the Pisco basin sedimentary sequence in the field, at different scales. Tuffs are often revealed by the sharp bottom discontinuity highlighted by gypsum wavy layers protruding from the outcrop (A). Normal grading and crystal concentrations at the base are common features (B), and black biotite concentrations cannot be overlooked even before cleaning the outcrop (C).

Fig. 4 - Tephra grain size distribution. Grain size distribution curves of four representative tephra.

Fig. 5 - SEM images. BSE images of different glass shard morphologies. A) bubble wall; B) vesciculated; C) stretched; D) with microlites.

Fig. 6 - Volcanic glass $\mathrm{K}_{2} \mathrm{O}$ vs $\mathrm{SiO}_{2}$ diagram. Glass composition of P2 sequence tephra layers. Major elements are shown as wt\% and recalculated to 100 to compare glasses with variable hydration.

Fig. 7A - Biotite $\mathbf{M g} / \mathbf{M g}+\mathbf{F e}+\mathbf{M n}$ vs Al diagram. Biotite chemical composition of $\mathrm{P} 2$ tephra. Al is shown as atoms per formula unit. B - Chemical ternary diagram of biotite phenocrysts. Biotite discrimination diagram: fields from Abdel-Rahman, 1994 J. of Petrology. $C=$ calcalkaline orogenic suites; $\mathrm{P}=$ peraluminous suites; A= anorogenic alkaline suites.

Fig. 8 - Correlations in biotite chemistry. $\mathrm{Ti} / \mathrm{Al}$ vs $\mathrm{Mg}_{\mathrm{v}}$ diagram of biotite phenocrysts from correlated tephra. $\mathrm{Mg}_{\mathrm{v}}$ is the ratio $\mathrm{Mg} /(\mathrm{Mg}+\mathrm{Fe}+\mathrm{Mn})$.

Fig. 9 - Stratigraphic sections correlated. Correlation of the measured stratigraphic sections of Cerro los

Table 1 - Representative analyses of glass shards.

Table 2 - Representative analyses of biotite phenocrysts. 
649 Figures and tables:

650

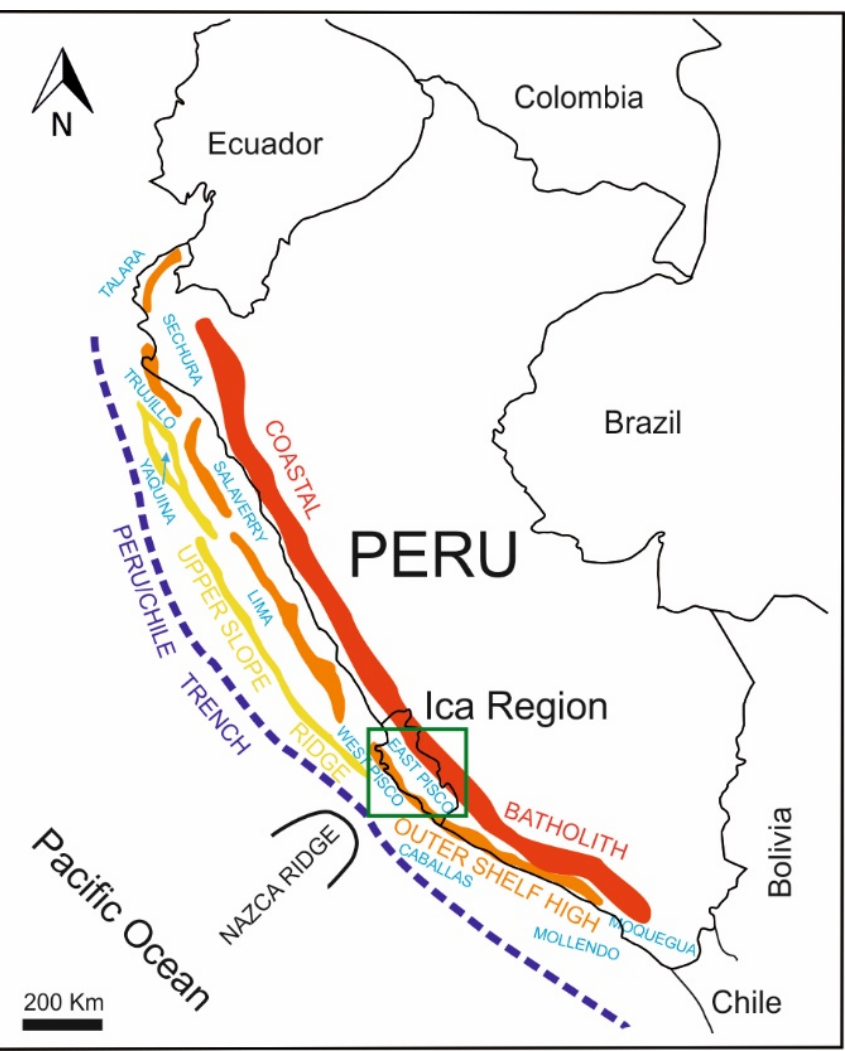

653

Fig.1

654

655

656

657 


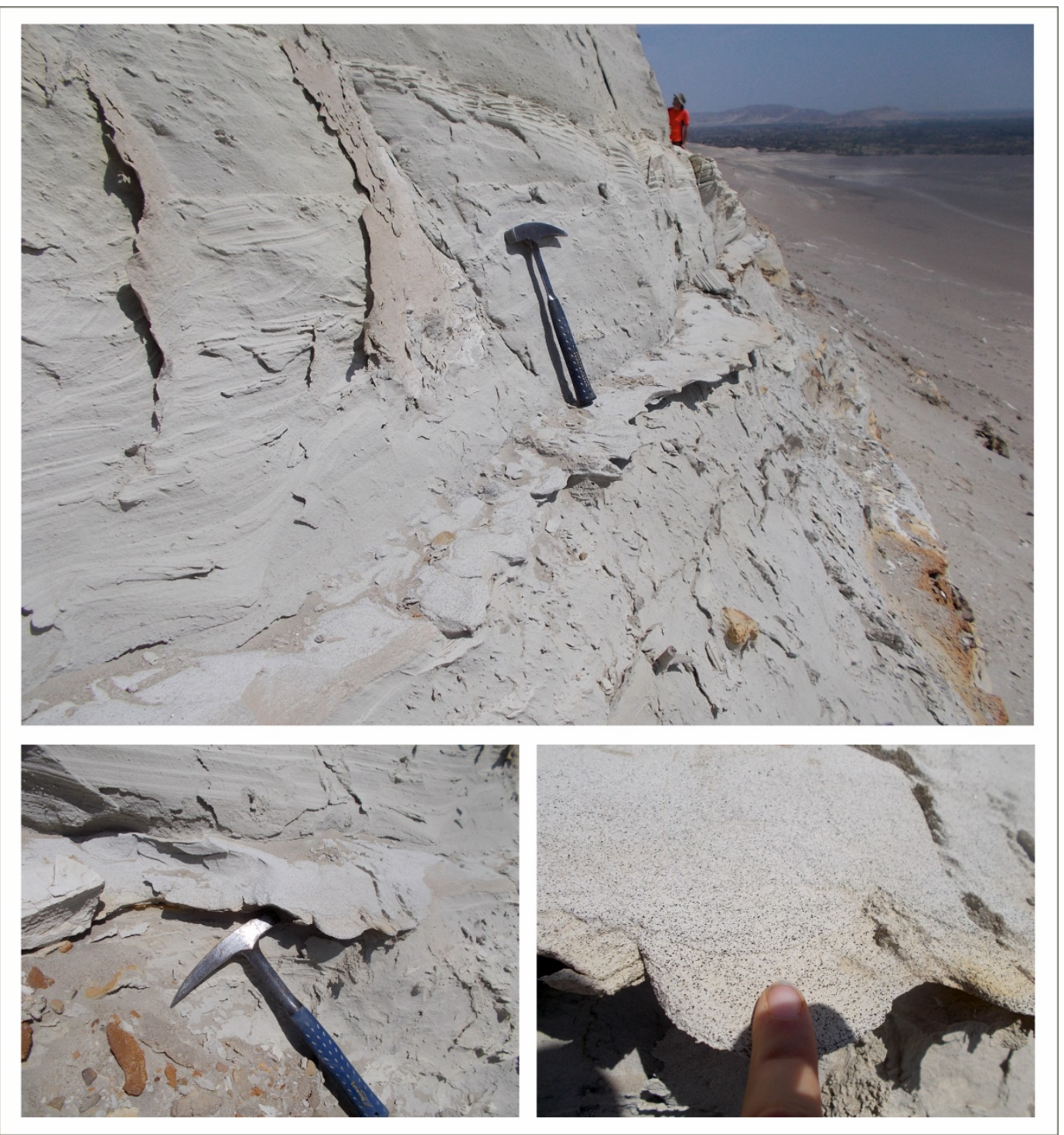

658

659

660

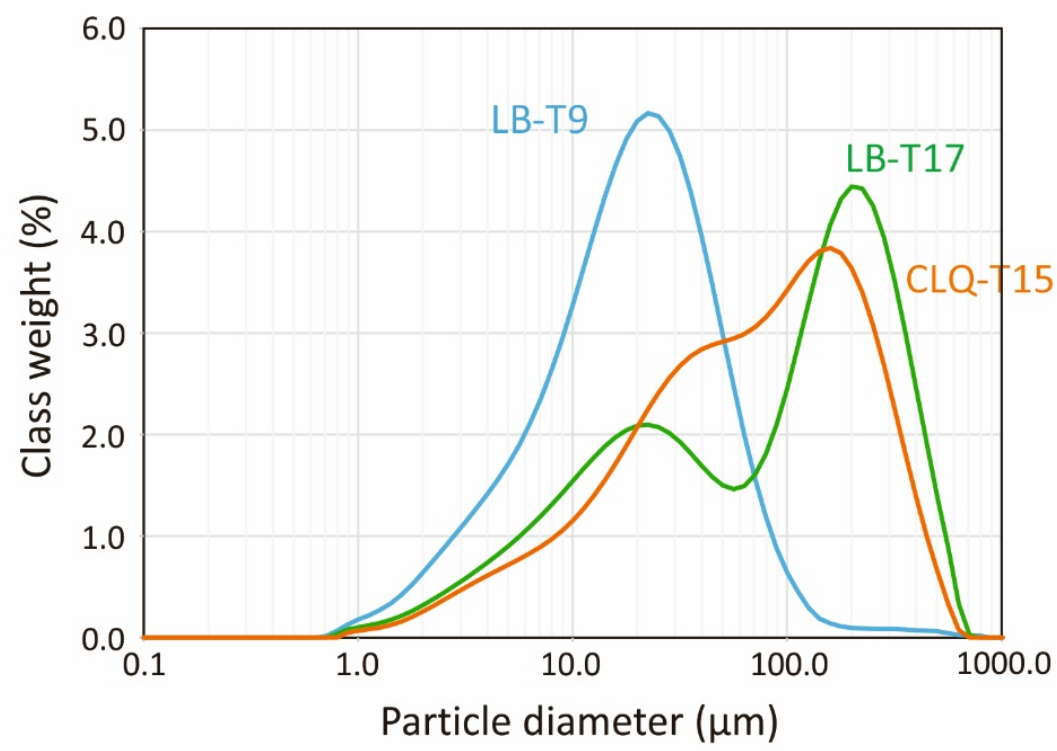

Fig.4-CLQ-T9a e phi 

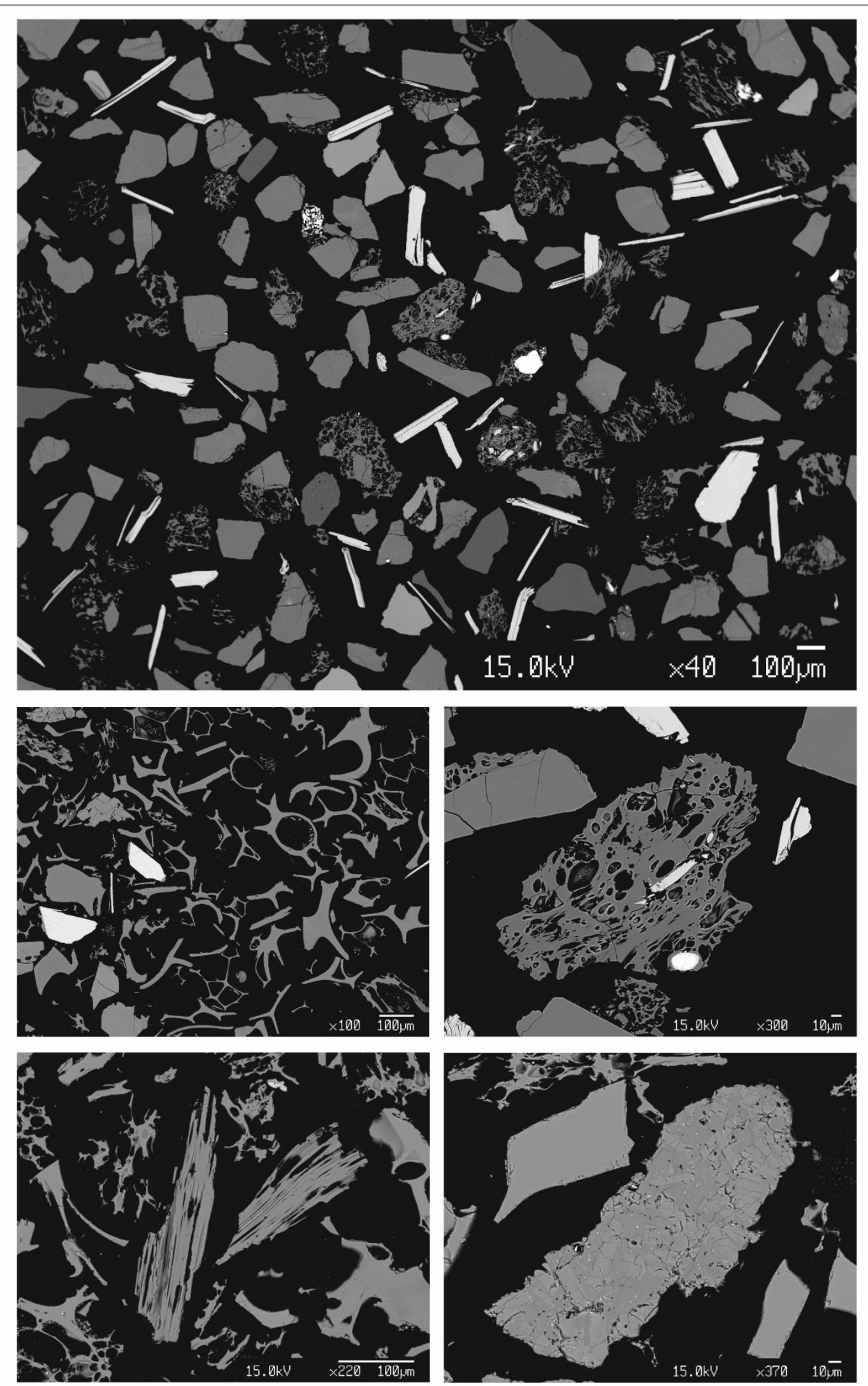


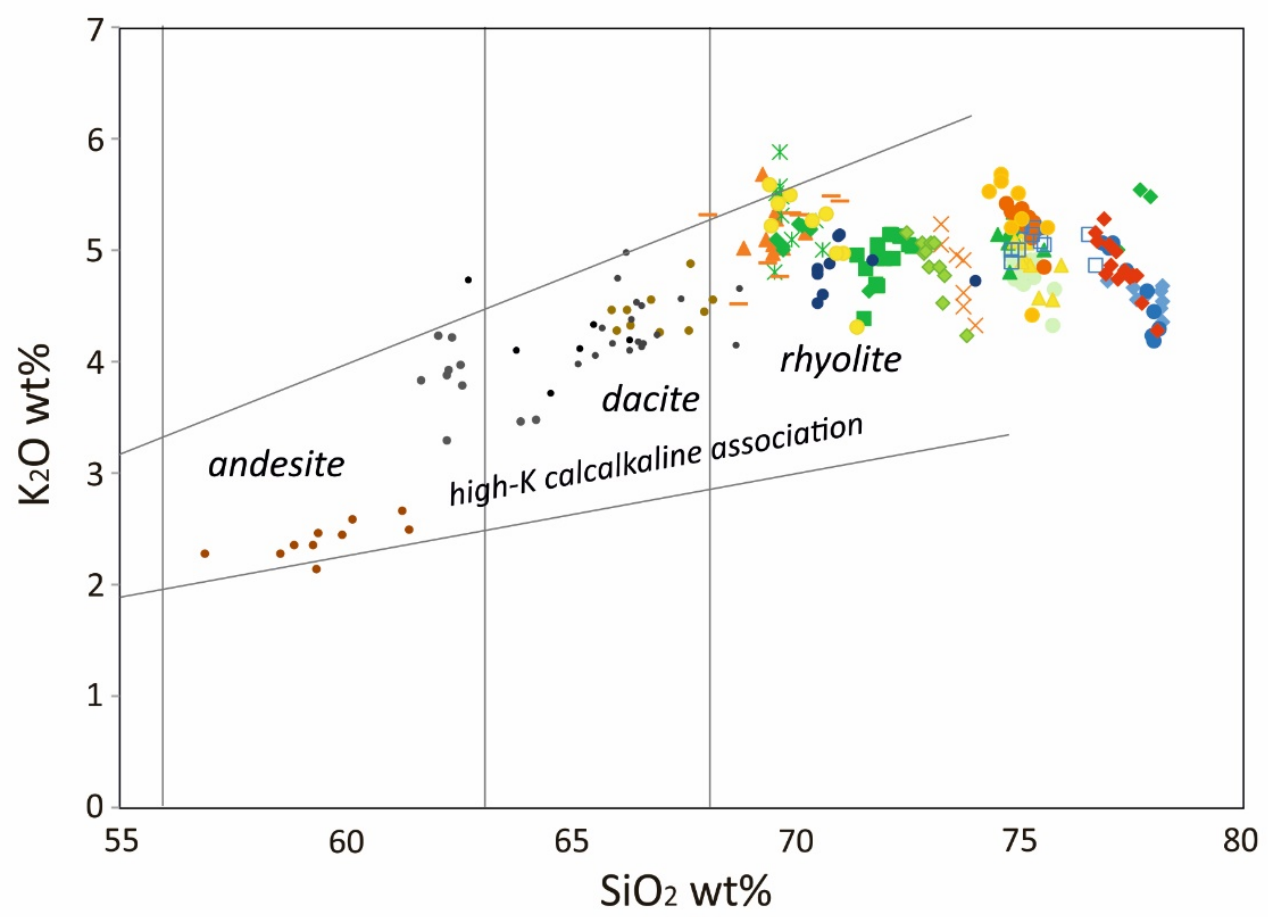
C. Blanco
- BL-T1
CLQ-T14
C. la Bruja
C. la Zorra
C. Colorado
CLQ-T15
LB16-T1
- LZ-T1
- CC-T17
- CLQ-T16
- LB-T2
+ LZ-T19
- CC-T22b
$\diamond$ CLQ-T21
+ LB-T3
- LB-T7
C. Cadenas de
C. Ios Quesos
$\times$ CLQ-T23
- LB-T8
- LB-T10 los Zanjones
- ANF-T4
CLQ-T1a
* CLQ-T9b
CLQ-T44
LB-T11
- LA-T31a
- CLQ-T45
* LB-T15
MH-T4
- ZANJ-T28
- CLQ-T12
$\triangle$ CLQ-T49
- LB-T17
- LB-T19a
C. Toro Chico
- CLQ-T13b
+ CLQ15-T5
- LB-T30
$\times$ TC-T1

672

673

674

Fig.6 
A)

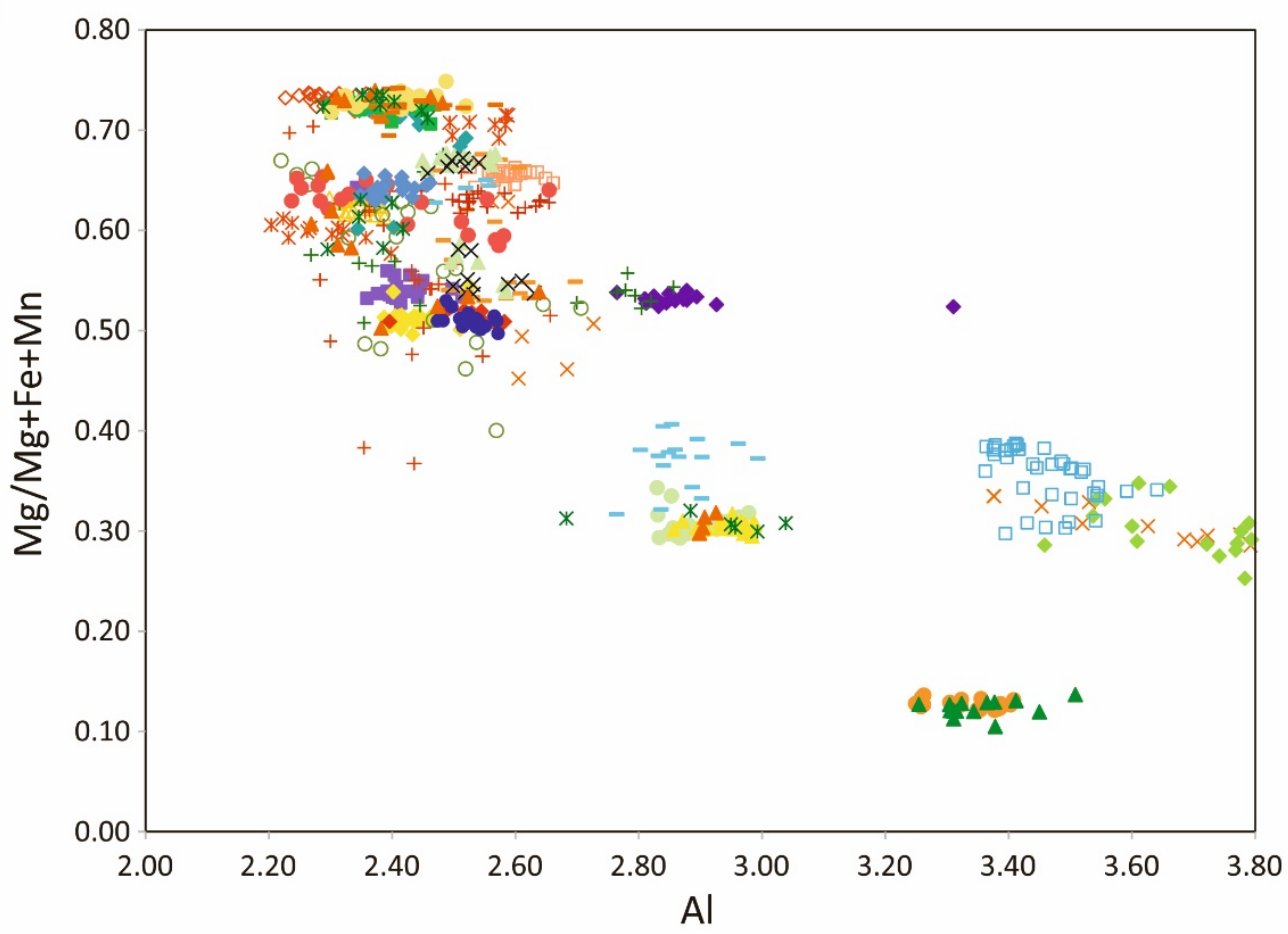
C. Blanco
- BL-T1
CLQ-T14
C. la Bruja
C. la Zorra
C. Colorado
CLQ-T15
LB16-T1
- LZ-T1
- CC-T17
- CLQ-T16
$\circ$ LB-T2
+ LZ-T19
- CC-T22b
$\triangle$ CLQ-T17
+ LB-T3
- LB-T7
- LB-T8
C. Ios Quesos
C. Cadenas de
- ANF-T4
CLQ-T1a
$\times$ CLQ-T23
- LB-T10 los Zanjones
* CLQ-T9b
LB-T11
- LA-T31a
- CLQ-T45
* LB-T15
CLQ-T49
- LB-T17
- CLQ-T12
- CLQ15-T4
LB-T19a
+ CLQ15-T5
$\square \mathrm{MH}-\mathrm{T} 4$
- ZANJ-T28
C. Toro Chico
- LB-T30
$\times$ TC-T1

B)

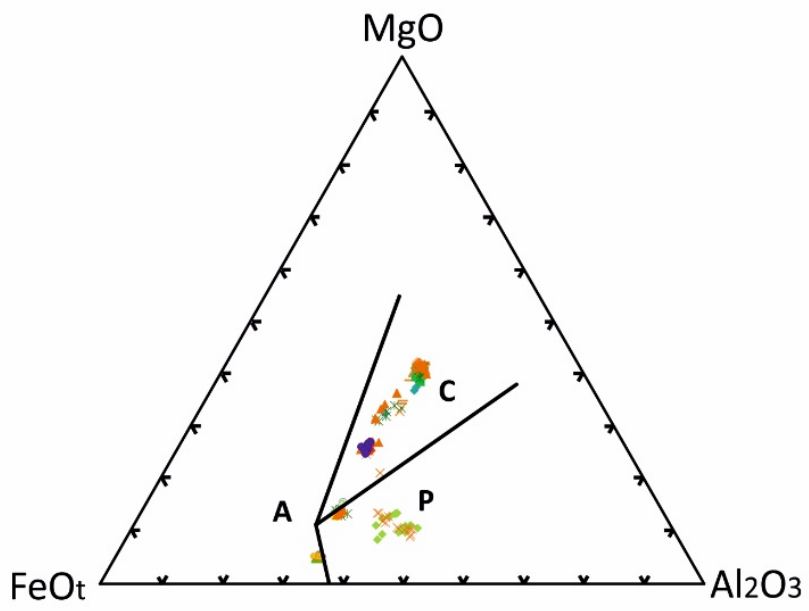

Fig.7 - Biotite compositions 


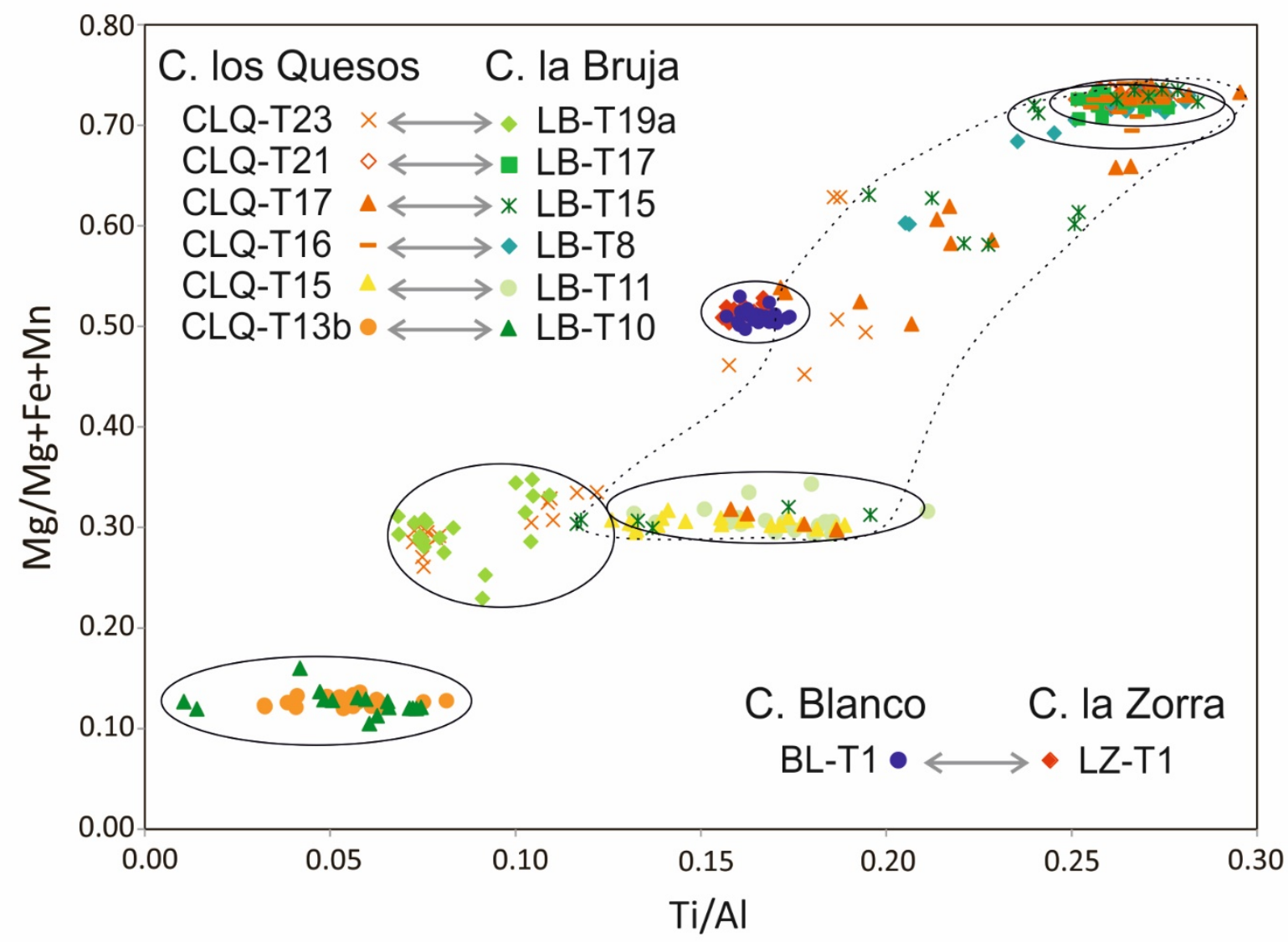

682

683

684

685

686

687

688

Fig.8 


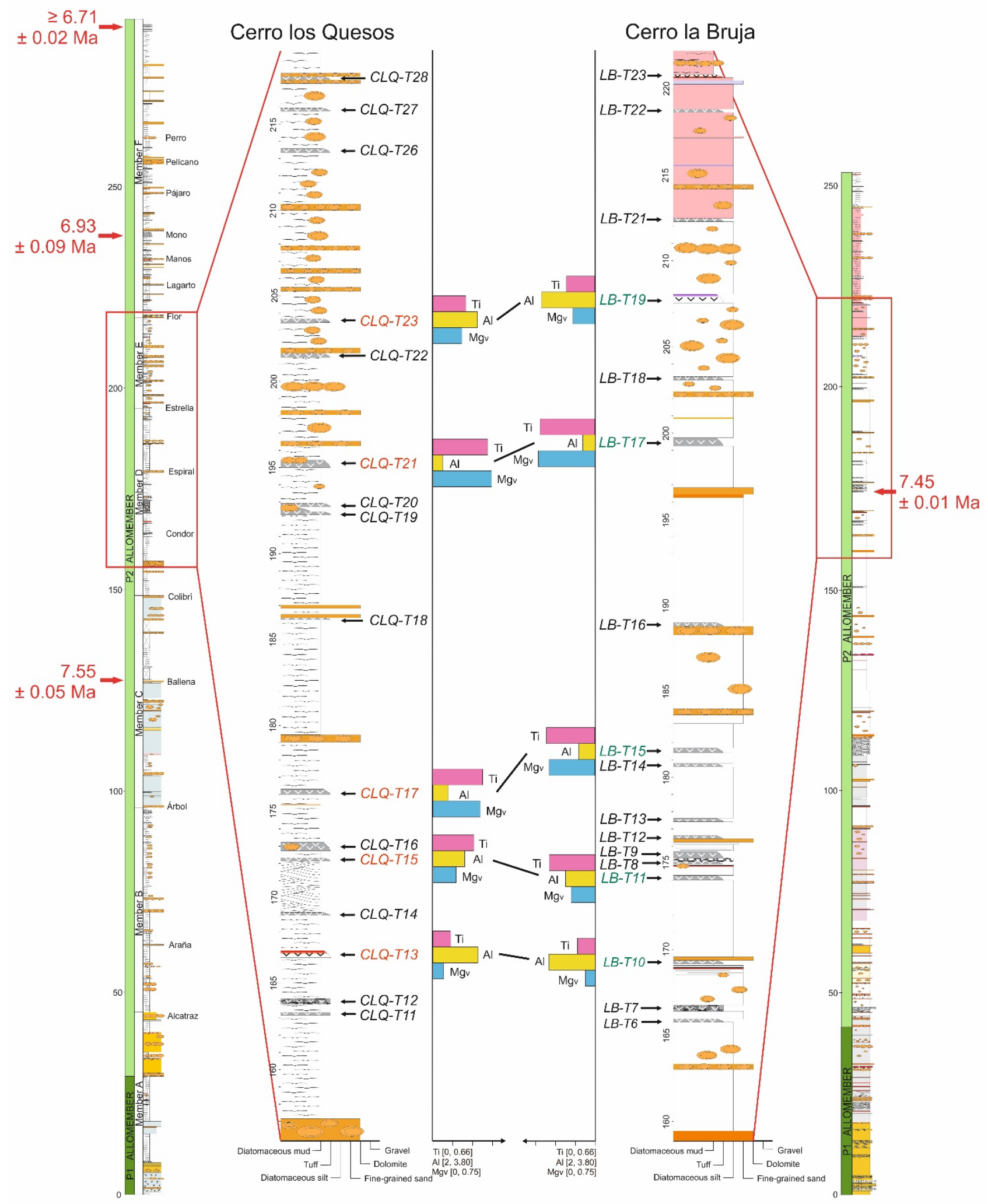

Fig.9 
697

698

699

700

701

702

703

704

705

706

707

708

709

710

711

712

713

714

715

716

717

718

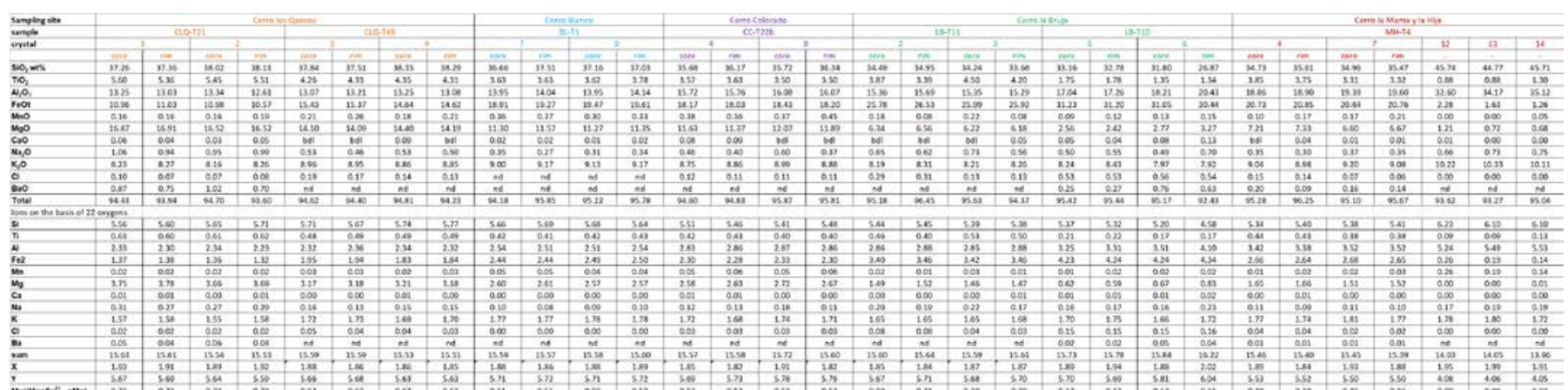

Table 2 